\title{
IDENTIFIKASI DAN HITUNG ANGKA KAPANG PADA KULIT APEL PASCA PANEN DI DAERAH BATU, MALANG
}

\author{
M. Yunas Alfanda ${ }^{1)}$ \\ Fakultas Ilmu Kesehatan, Universitas Maarif Hasyim Latif Sidoarjo \\ yunasalfanda@gmail.com
}

\begin{abstract}
ABSTRAK
Kurangnya kesadaran masyarakat terhadap kesehatan pangan, membuat banyak terjadi kasus kontaminasi bahan pangan oleh mikroba. Salah satu mikroba yang mencemari bahan pangan adalah kapang. Penelitian ini bertujuan untuk mengidentifikasi dan menghitung jumlah kapang penyebab pembusukan pada kulit buah apel pascapanen di daerah Batu, Malang. Kapang adalah jamur multiseluler yang memiliki hifa yang menjadi ciri khas pembeda dengan khamir. Selain itu, kapang juga dapat menghasilkan mikotoksin yang berbahaya bagi kesehatan manusia. Sampel diambil secara acak dari perkebunan apel di daerah Batu. Identifikasi menggunakan metode Mounting Block dan media Saboroud Dextrose Agar (SDA), dan penghitungan jumlah kapang menggunakan metode Angka Kapang Khamir Cawan Tuang. Identifikasi mengguanakan mikroskop dengan perbesaran 400x, diamati berdasarkan morfologi hifa, konidia dan konidiofornya. Hasil penelitian menunjukkan adanya Aspergillus niger pada kulit buah apel sebanyak $5 \times 10^{1}$ sampai $7 \times 10^{1}$. Kapang jenis ini paling mudah dijumpai pada buah-buahan. Selain pada buah-buahan, Aspergillus niger juga bisa diisolasi dari tanah, udara, dan serasah daun. Perlakuan buah apel pascapanen dan waktu penyimpanan berpengaruh pada jumlah kapang yang tumbuh. Batas cemaran mikroba untuk buah apel (kategori buah kering) pada jenis cemaran mikroba kapang adalah $<5 \times 10^{1}$.
\end{abstract}

Kata Kunci : Kulit apel, Kapang, Aspergillus niger

\section{PENDAHULUAN}

Apel adalah buah yang sering dikonsumsi dan tidak asing bagi msyarakat Indonesia. Buah Apel sangat mudah dijumpai dan memiliki manfaat yang tidak sedikit bagi kesehatan. Hidrat arang, lemak, protein, kalsium, fosfor, besi, vitamin $\mathrm{A}$, vitamin $\mathrm{B} 1$, vitamin $\mathrm{C}$ dan kandungan air merupakan kandungan gizi yang ada di dalam buah apel (Arisandi dan Andriani, 2008). Di samping manfaat yang banyak, apel juga beresiko sebagai sumber penyakit jika terkontaminasi.

Kontaminasi pada apel dapat terjadi karena kesadaran masyarakat tentang kesehatan pangan kurang. Kontaminasi yang terjadi dapat melalui proses pemanenan yang kurang bersih atau proses distribusi apel yang kurang baik, bahkan melalui lingkungan perkebunan yang tidak sehat. Cara pengemasan yang tidak tepat, kerusakan fisik akibat benturan dan perubahan kimia selama proses penyimpanan juga menjadi faktor yang menyebabkan tingginya kontaminasi kapang pada buah (Miskiyah dkk., 2010). Untuk menjamin bahan pangan aman dan layak dikonsumsi, dibutuhkan keamanan pangan (Ilyas, 2007).

Dari uraian di atas perlu dilakukan penelitian adanya mikroorganisme kapang dan jumlah kapang pada kulit buah Apel pasca panen di daerah Batu, Malang untuk mengetahui layak atau tidaknya buah apel tersebut untuk dikonsumsi. 


\section{METODOLOGI PENELITIAN}

\section{Tempat dan Waktu Penelitian}

Penelitian dilakukan di Laboratorium

Mikrobiologi Fakultas Ilmu Kesehatan

Universitas Maarif Hasyim Latif dan Laboratorium Mikrobiologi Balai Riset dan Standardisasi Industri Surabaya pada bulan Juli - Agustus 2019.

\section{Peralatan Penelitian}

Alat - alat yang dibutuhkan dalam penelitian ini yaitu autoclave, cawan petri, bunsen, mikroskop, pipet skala, pipet volume, erlenmeyer, ose, tabung reaksi.

\section{Bahan Penelitian}

Bahan yang digunakan antara lain sampel kulit apel, Buffer Phospat, aquades, media SDA (Sabouroud Dextrose Agar).

\section{Prosedur Penelitian}

\section{Pengambilan Sampel}

Sampel buah apel yang diambil berasal dari perkebunan di Daerah Batu, Malang secara acak. Sampel diambil setelah melalui proses panen dan siap untuk di distribusi ke tempat lain. Guna meminimalisir terjadinya kontaminasi, buah apel yang akan diambil kulitnya dimasukkan ke dalam kantung plastik dan diletakkan dalam box sterofoam.

\section{Pembuatan Media SDA (Sabouroud} Dextrose Agar

Menimbang Nutrient Agar sebanyak 2 gram dan Glukosa sebanyak 4 gram. Masukkan ke dalam erlenmeyer kemudian dilarutkan dengan $100 \mathrm{ml}$ aquades. Tutup erlenmeyer menggunakan kapas kemudian dipanaskan (tidak sampai mendidih) untuk melarutkan media. Setelah larut dilakukan sterilisasi media dalam erlenmeyer pada suhu $121^{\circ} \mathrm{C}$ selama 20 menit, dan ditambahkan larutan Chlorampenicol sebanyak $20 \mathrm{ml} /$ liter yang bertujuan sebagai penghambat pertumbuhan bakteri (Wawan, 2006).

\section{Hitung Angka Kapang}

Timbang $25 \mathrm{~g}$ kulit buah apel dan masukkan dalam erlenmeyer berisi $225 \mathrm{ml}$ Buffer Phosphate. Kemudian pipet $1 \mathrm{ml}$ dan masukkan dalam tabung reaksi berisi $9 \mathrm{ml}$ Buffer Phospat berarti pengenceran $10^{2}$. Untuk pengenceran $10^{3}$ diambil dari tabung reaksi $10^{2}$ sebanyak $1 \mathrm{ml}$ dan dimasukkan dalam tabung reaksi berisi $9 \mathrm{ml}$ Buffer Phospat. Dan masingmasing pengenceran dipipet $1 \mathrm{ml}$ dan dituang pada media SDA plate.

Inkubasi dilakukan selama 1-7 hari pada suhu ruang dan harus dilakukan pengamatan setiap hari.

\section{Identifikasi Kapang}

Potongan media SDA berukuran $1 \mathrm{x} 1 \mathrm{~cm}$ dimasukkan dalam plate steril berisi objek glass, segitiga kaca, kertas saring dan cover glass. Letakkan di atas objek glass dan diberi alas kertas saring di bawah objek glass. Dengan menggunakan ose jarum, biakan diambil dari media SDA slant dan ditanam dengan cara ditusuk pada media Mounting Block. Cara penusukan adalah pada 4 titik sudut media Mounting Block. Kemudian tutup dengan cover glass. 


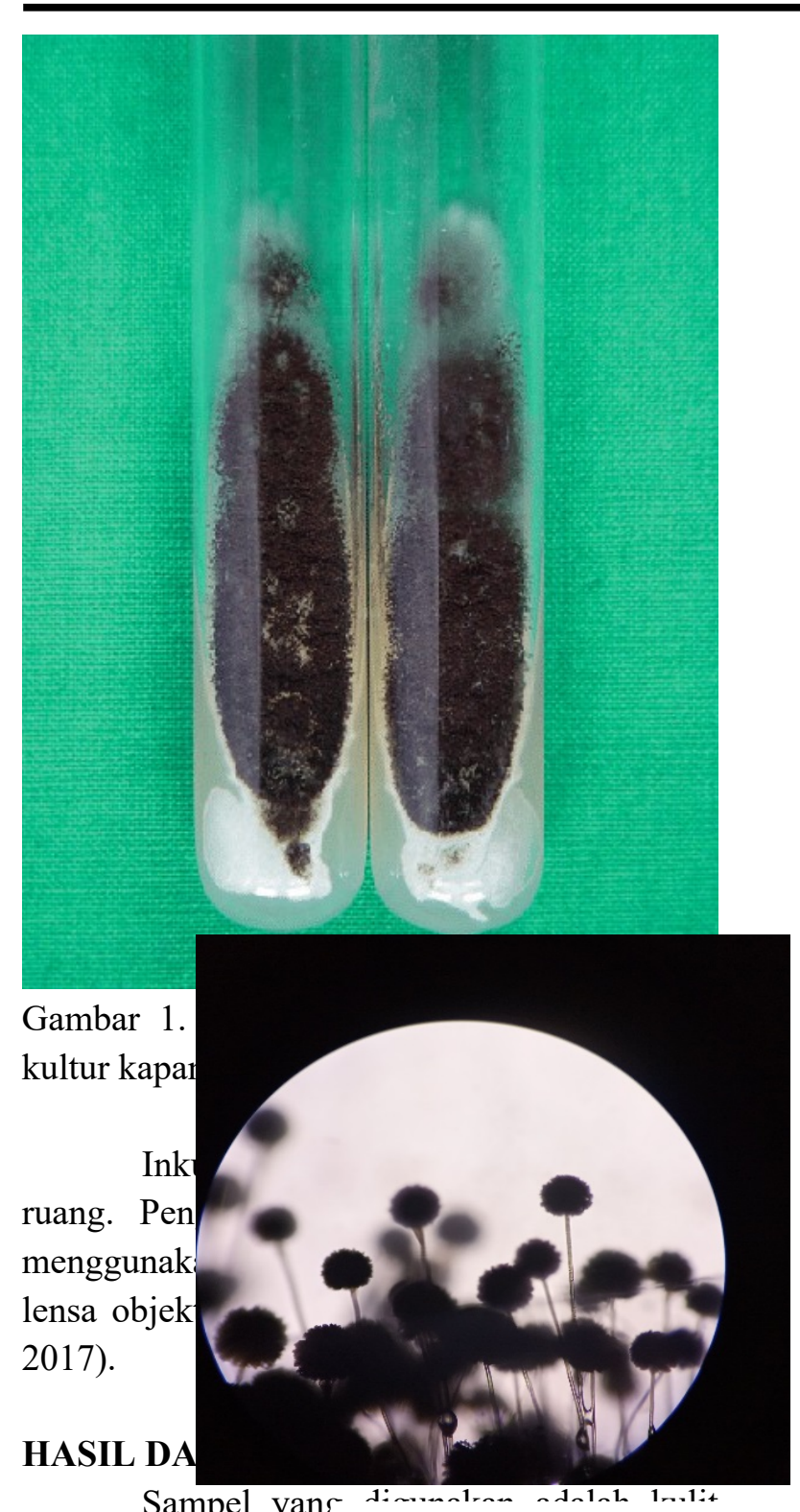

Berikut hasil yang didapat disajikan dalam bentuk tabel.

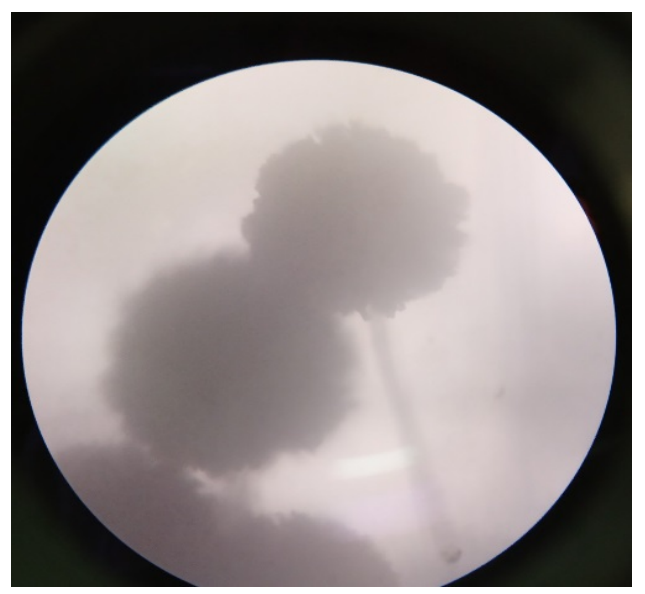

buah apel yang c Gambar 2. Hasil Identifikasi Kapang pada Kulit Buah Apel

perkebunan yang berbeda daerah Batu, Malang. Cara menentukan Angka Kapang dengan metode Angka Kapang Khamir (AKK).

\section{Hasil Uji Angka Kapang dan Identifikasi}

Hasil yang dicantumkan adalah hasil

$$
\text { yang melebihi batas }
$$

Tabel 1. Data Hasil Identifikasi dan Hitung Angka Kapang

yang ditetapkan oleh

SNI mengenai batasan cemaran mikroba untuk buah kering, tercantum pada SNI 7388:2009.

\begin{tabular}{lccc} 
No. & Kode Sampel & Hasil Identifikasi & Jumlah Kapang \\
\hline 1. & $\mathrm{~A}$ & & \\
2. & $\mathrm{~B}$ & & \\
3. & $\mathrm{C}$ & & \\
4. & $\mathrm{D}$ & Aspergillus niger & $6 \times 10^{1}$ \\
5. & $\mathrm{E}$ & Aspergillus niger & $5 \times 10^{1}$ \\
6. & $\mathrm{~F}$ & Aspergillus niger & $7 \times 10^{1}$ \\
7. & $\mathrm{G}$ & Aspergillus niger & $7 \times 10^{1}$ \\
8. & $\mathrm{H}$ & & \\
9. & $\mathrm{I}$ & & \\
10. & $\mathrm{~J}$ & & \\
11. & $\mathrm{~K}$ & & \\
12. & $\mathrm{~L}$ & & \\
13. & $\mathrm{M}$ & & \\
14. & $\mathrm{~N}$ & Aspergillus niger & $5 \times 10^{1}$ \\
15. & $\mathrm{O}$ & Aspergillus niger & $6 \times 10^{1}$ \\
16. & $\mathrm{P}$ & Aspergillus niger & $6 \times 10^{1}$ \\
17. & $\mathrm{Q}$ & Aspergillus niger & $7 \times 10^{1}$ \\
18. & $\mathrm{R}$ & Aspergillus niger & $6 \times 10^{1}$ \\
19. & $\mathrm{~S}$ & $\mathrm{~s}$ & \\
20. & $\mathrm{~T}$ & &
\end{tabular}
buah apel, didapatkan hasil 9 dari 20 sampel
melebihi batas yang diijinkan oleh SNI. Hasil Identifikasi terhadap sampel didapatkan kapang Aspergillus niger. Adanya kapang Aspergillus niger pada bahan pangan akan membahayakan konsumen jika masuk ke tubuh dalam jumlah besar dan secara terus menerus. Hal ini terjadi karena kapang dapat memproduksi 
mikotoksin (Miskiyah dkk., 2010).

Mikotoksin merupakan hasil metabolit sekunder dari kapang yang beracun. Adanya mikotoksin dapat menimbulkan mikotoksis yang menyebabkan perubahan klinis dan patologis seperti kanker hati, pembengkakan otak, ginjal hingga gangguan syaraf (Miskiyah dkk., 2010). Mikotoksis terjadi karena konsumsi hasil metabolisme beracun dari kapang yang diproduksi oleh Aspergillus, Rhizopus, dan Penicillium (Dewanti, 2012).
Mikotoksin yang masuk ke dalam tubuh tidak dapat dirasakan langsung gejalanya oleh konsumen karena bersifat kumulatif. Indikasi adanya cemaran mikotoksin dapat diketahui dari infestasi kapang pada kondisi tertentu (Miskiyah dkk., 2010).

\section{Kesimpulan}

Dari hasil penelitian didapatkan kapang Aspergillus niger. Dari 20 sampel kulit buah apel didapatkan hasil koloni pada kode Sampel E sebanyak $6 \times 10^{1} \mathrm{koloni} / \mathrm{gr}$, sampel F $5 \times 10^{1}$, sampel G $7 \times 10^{1}$, sampel H $7 \times 10^{1}$, sampel P sebanyak $5 \times 10^{1}$, sampel Q sebanyak $6 \times 10^{1}$, sampel R sebanyak $6 \times 10^{1}$, sampel S sebanyak $7 \times 10^{1}$, sampel T sebanyak $6 \times 10^{1}$.

\section{UCAPAN TERIMAKASIH}

Ucapan terimakasih disampaikan kepada Tuhan Yang Maha Esa yang telah memudahkan dan merahmati dalam penyusunan sampai menyelesaikan penelitian ini. Serta kepada ibu dan bapak dosen pembimbing yang telah memberikan ilmu dan waktu untuk memberi arahan, sehingga dapat terselesaikan dengan baik.

\section{DAFTAR PUSTAKA}

Arisandi, Yohana, and Yovita Andriani. Khasiat tanaman obat. Pustaka Buku Murah, 2008.

Aristyawati, N.P.D., Ni Nyoman P., Ni Made I.H.A., Agus S.D. 2017. Cemaran Aspergillus flavus Penghasil Aflatoksin B1 pada Jagung Manis (Zea Mays saccharata) selama Penyimpanan. Jurnal ITEPA (6):2.

Booth, C. 1971. Methods in Microbiology. Vol 4. Academic Press, London.

Dewanti dkk. 2012. Hidrolisis Ampas Tebu Menjadi Glukosa Cair oleh Kapang Trichoderma Viride. Jurnal Teknologi Pertanian

Iskandar, Y.M., 2002. Isoflavonoida Hasil

Fermentasi Kedelai Menggunakan Inokulum Kultur Campuran, Prosiding Semnas XI. Jasakiai. Yogyakarta.

Ilyas, Muhammad. 2007. Isolasi dan Identifikasi Mikoflora Kapang pada 
Sampel Serasah Daun Tumbuhan di

Kawasan Gunung Lawu, Surakarta, Jawa Tengah. UNS Surakarta. Solo.

Miskiyah, Christina W., dan Wisnu B. 2010. Kontaminasi Mikotoksin pada Buah Segar dan Produk Olahannya serta Penanggulangannya. Jurnal Litbang Pertanian 29 (3).

SNI 7388-2009. 2009. Batasan

Maksimum Cemaran Mikroba dalam

Pangan. Badan Standardisasi Nasional.

Jakarta

Traquair, J. 2000. Fungi and Mycorrhizae. London. 